\title{
Changing Cultural Practices among the Rural and UrbanMising Tribe of Assam, India
}

\author{
${ }^{1}$ Pahari Doley \\ ${ }^{1}$ Research Scholar, Gauhati University, India
}

\begin{abstract}
The colorful life of the people, their traditional customs, festivals and dances are some of the components of the rich cultural diversity of India as well as its north-eastern region including Assam. Culture is not a static identity and keeps changing. The changing environmental development makes internal adaptation necessary for culture. Thus, a lot of changes have also been observed in the Mising culture too. The impact of urbanisation and modernization has brought a major eeconomic and socio-cultural transformation among the Mising tribe of Assam. Their society is changing not only in the aspects of socio-economic and political areas butalsointraditional beliefs andcultural practices. With the above background, an attempt has been made to understand the traditional and cultural practices among the Mising Tribe of Assam in particular and ruralurban context in general.
\end{abstract}

Keywords: Mising Tribe, culture, cultural diversity, cultural Practices

\section{Statement Of The Problem}

The Misings, belonging to Tibeto-Burman ethnic group and formerly known as the Miris, which constitute the second largest scheduled tribe (Plains) group in Assam, have been playing a significant role in the culture and economy of the greater Assamese society in general and tribal society in particular. They with 5.9 lakh population (17.8 per cent of the state's total tribal people) as per 2001 Census are mainly concentrated in the riverine areas of Dhemaji, Lakhimpur, Dibrugarh, Tinsukia, Sibsagar, Jorhat, Golaghat and Sonitpur districts of Assam. It is worth mentioning that Dhemaji district alone constitutes $31.7 \%$ of the total Misings in the state, followed by Lakhimpur (28.2\%) and Jorhat (15.7\%) districts. Moreover, agriculture being their main occupation, as high as $85.6 \%$ of main workers is engaged as cultivators in the state, which is the highest among all the tribes of Assam. The majority of the Mising people are still living in the flood affected and isolated areas with old age traditions, and modern civilization has practically left them almost untouched in many aspects. This colourful ethnic group living amidst the fellow non-tribal Assamese people for many centuries has been able to maintain its traditional socio-cultural traits un-impaired in spite of the changes that have taken place in the socio-politico-religious life of Assam (Bordoloiet al, 1987).

Having the tradition of living along the banks of rivers, the habitats of Misings have been constantly exposed to floods and erosion, for which they have to often shift from one place to another (Doley, 2008). Although majority of them are still living in rural areas, it is noticed that for better socio-economic conditions, employment opportunities, accessibility, etc rural to urban migration either temporarily or permanently is gaining ground among the Misings in recent times, which have resulted in adoption of new urban culture sometimes at the cost of age-old cultural traditions.In respect of Mising societies, although the Misings are maintaining the traditional customs, some changes have been noticed in their life and culture which are affecting the core of their culture. The spread of modern education, science and technology, etc. has also brought about drastic changes in the religious beliefs and socio-economic life of the Misings. The Misings are undergoing the process of modernisation, acculturation and urbanization, and the impact of these factors on them is resulting in erosion of their traditional life and folk culture.

In consideration of the above, the present study entitled "Changing Cultural Practices Among the Rural and Urban Mising Tribe of Assam, India" is taken up to understand the changing pattern of cultural and traditional practices among the Mising tribe in the selected rural and urban areas of Mising villages/locality of Assam.

\section{Significance Of The Study}

India as well its north-eastern part including Assam is the meeting ground of many diverse cultures and population of ethnic and distinctive tribes that co-exist peacefully, each unique in its traditions, culture, dress and exotic ways of life. However, due to their interactions among various social groups, the strength of traditional norms and ways of life of those tribes has been weakened. The Misings, one of the major tribes of Assam, are also found to have changed to some extent in terms of their social, cultural, economic and traditional practices, although they are maintaining the traditional or customary cultural pattern since time immemorial. 
Changes are noticed in their life and socio-cultural practices both in rural and urban areas which are affecting the core of their culture. However, the changes are rapid in urban areas as compared to the rural areas in the state. Thus, to understand the changes among the Misings in urban and rural areas of Assam, two areas namely Jonai Revenue Circle and Guwahati City have been selected so as to understand the various changes in cultural practices among them. Although there have been many tribal studies in India based on tribal economy, land alienation, socio-economic development, tribal culture, etc, the studies related to the Mising Tribe of Assam are still highly limited. This study would also help explore the prevailing changes in cultural practices of the Misings in Assam. Moreover, the findings derived from the study would provide inputs to the development planners and policy makers for overall progress of the tribal communities in general and the Misings in particular. Hence, the present research work bears immense academic significance and practical utility particularly in understanding the Mising tribe in urban and rural contexts in proper perspective.

\section{Objectives}

The major objectives of the present study are:

1. to study the pattern of changes in the cultural practices among the Mising of rural and urban areas of Assam;

2. to analyze the level of changing cultural practices among the Misings in rural and urban conext; and

3. to understand the prevailing trend of cultural practices among the rural and urban Misings of Assam.

\section{Database And Methodology}

The study is based on both secondary and primary data. The secondary data related to various attributes of population among the Mising tribe in particular and all scheduled tribes in general have been obtained from Census of India, 2001. Besides, existing literature available in various journals, books, Ph.D. and M.Phil.dissertations related to the topic has been consulted with a view to develop a broad theoretical framework of the present research in right perspective.Necessary primary data have been collected at household level through sample survey with the help of a well-designed survey schedule from SomkongPagro and No.4 Ramdhan villages and JonaiBazar under Jonai revenue circle of Dhemajidistrict and various localities of Guwahati city, viz. Hengerabari, Kahilipara-Sonaighuli and Barbari-Panjabari.Samples of 30 households from each selected area under Jonai revenue circle and 60 households from different localities under Guwahati city have been considered for collection of primary data to understand the rural-urban and location-specific variations in socio-economic conditions among the Misings. The sample households in each area and urban locality have been selected purposively with locational and economic considerations towards having adequate representation of the way of life and various other characteristics of the Misings.

The data obtained from both secondary and primary sources have been processed and analysed using some simple but meaningful statistical techniques for objective and logical interpretation. The quantitative techniques adopted for the analysis are simple ratios or percentages, and certain statistical measures. The data so processed and analysed have been represented in the forms of maps and diagrams with suitable cartographic techniques for proper illustration of the patterns. Conclusions on the study area are drawn on the basis of the results derived from the data analysis and personal experience gathered through the observations during field study.

Table 1: Sample Design of the Survey Villages and Urban Localities of Misings, 2001 \& 2012

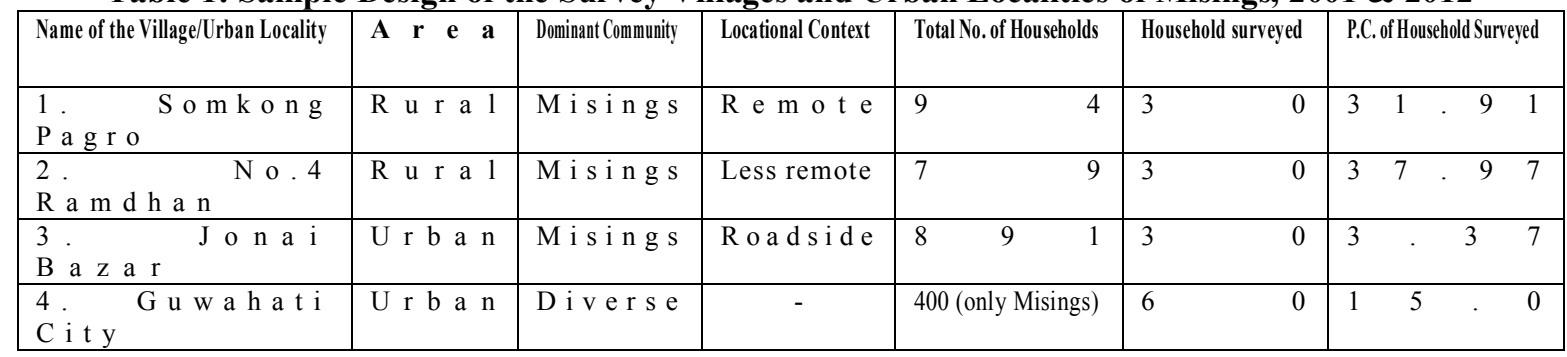

Source: Census of India, Assam, 2001 and Field Survey, 2012.

\section{Geographical Background Of The Study Area}

Assam, located in the tropical latitudes $\left(24.3^{0} \mathrm{~N}\right.$ and $\left.28^{\circ} \mathrm{N}\right)$ and eastern longitudes $\left(89.5^{\circ} \mathrm{E}\right.$ and $96.1^{0}$ E), is the most populous state in North-East India. It is surrounded on three sides by hills and mountains. The rivers Brahmaputra and Barak, in the north and south respectively, carve out deep valleys, which represent the major part of the state. Between the two valleys there lies a strip of highland made up by hills and plateaus (Taher, 2007). The state covers an area of 78,438 $\mathrm{km}^{2}$. It is surrounded by Bhutan and Arunachal Pradesh on the north; by Mizoram, Meghalaya and Tripura on the south; by Nagaland and Manipur on the east; and by West 
Bengal and Bangladesh on the west. It is connected with the mainland of India through a narrow corridor of 40 $\mathrm{km}$ width in West Bengal in the west. (Fig.1)

Jonai revenue circle, one of the case study areas, is located in Dhemaji district of Assam in the extreme east. It is about $550 \mathrm{~km}$ away from the capital city of Guwahati. Covering a total geographical area of 1,111.81 sq km, it is bounded by Arunachal Pradesh in the north, Lali and Brahmaputra rivers in the south, Sipiyariver and Sadiya sub-division of Tinsukia district in the south-east and Simen river in the west. The head-quarters of the revenue circle, Jonai is located at $95.16^{\circ} \mathrm{E}$ and $27.77^{\circ} \mathrm{N}$. The Jonai revenue circle itself constitutes the Jonai sub-division. Its only community development block MurkongSelek is a tribal development block with 15 GaonPanchayats. Excepting the Jonai Census town the whole subdivision is classified as rural, and as such, agriculture occupies the predominant position. Although Jonai sub-division is inhabited by many tribal and nontribal communities, the proportion of the Misings is highly significant among the tribes. The area is connected by 'MurkongSelek' railway station and NH-52 with rest of the state.

Guwahati, another case study area, is the capital city of Assam and it is the largest and fastest growing commercial, industrial, educational centre inthe entire north-eastern region of India. Geographically, it is located in the southern bank of the river Brahmaputra between $26^{\circ} 05^{\prime}$ to $26^{\circ} 15^{\prime} \mathrm{N}$ Latitude and $91^{\circ} 35^{\prime}$ to $91^{\circ} 55^{\prime} \mathrm{E}$ Longitudes covering an area of $216 \mathrm{~km}^{2}$. It is also considered to be the "Gateway" to the north-eastern regionof India, as it is in the junction of many national highways, railways and airways of the region. Such a situation has resulted in rapid population growth in the city due to great influx of people from different parts of thecountry and from within the state.Although linguistically Assamese people constitute the majority of the city's population, it is of cosmopolitan character, as the city is also inhabited by Bengali and Hindi speaking non-tribal people and Boro, Rabha, Karbi and Mising speaking tribal people. The Misings in the city are largely concentrated in Hengerabari, Kahilipara-Sonaighuli and Barbari-Panjabari areas.

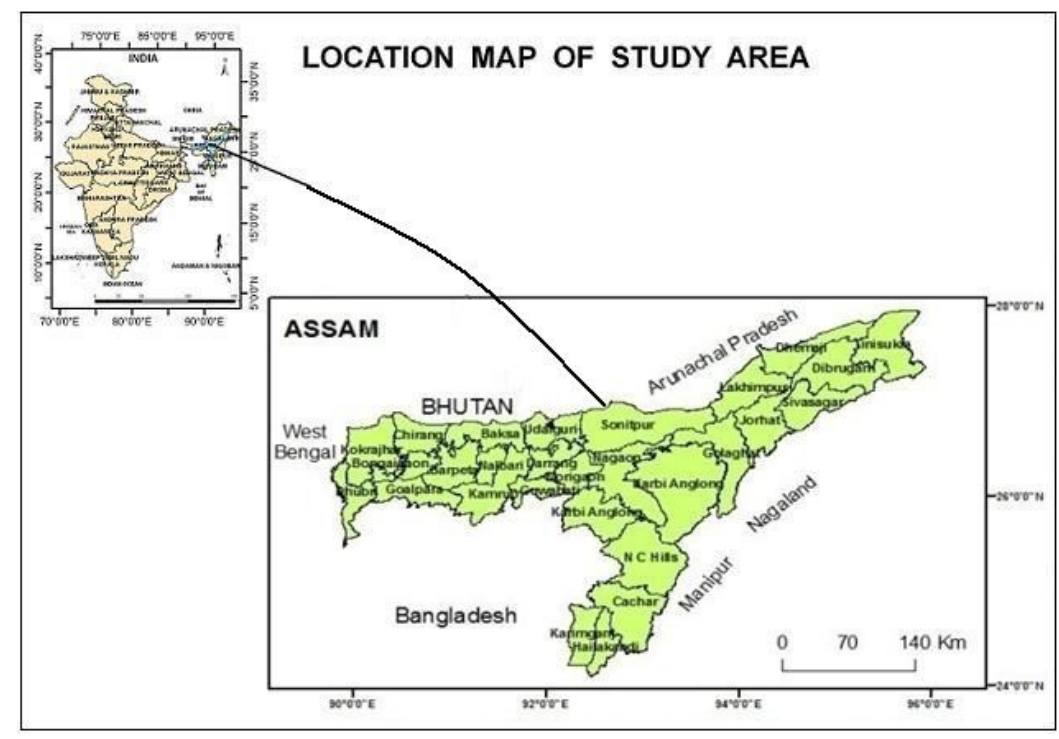

Fig.1

\section{Discussions}

\subsection{Changing Pattern of language spoken and religion among the Misings}

"Language is not only a tool of communication, but it also has ethnic, socio-cultural and political implications. Various ethnic groups in the North-East have their own dialects. These are often seen by those who use them as languages in their own right. In the north-eastern part of India the diverse ethnic groups use several languages. But the dominant language of the larger community has a pre-eminent place. Assam also has remarkable linguistic diversity. Bilingualism and sometimes trilingualism is common in both rural and urban areas even among the unlettered. This is because when a family, a kin group or a community, moves from one region to another, its members acquire the language of their new place of domicile without giving up their native dialect. Settlement of outsiders has also helped in spreading bilingualism or trilingualism in the region"(Verma). Among the Mising population, it is found that most of the population from the younger generation has forgotten their own dialect which is a serious threat for the survival of the socio-cultural practices of the Misings.

Changes are seen with respect to religious beliefs and practices as different forms of Hinduism and other religions have penetrated into their culture (Pegu, 2006). The original faith and belief of Misings is Do:nyi 
Polo, the Supreme Being who created the universe in all the elements. This belief still remains in their hearts and and dominates their thinking and movement (Tukbo, 2005). The Mising religious system has become admixture of both neo-vaisnavism and animism. Theyhave become Hinduised because they worship Hindu deities, observe Hindu religious celebrations, etc. But at the same time they also profess animism. So, they may be also called tribal Hindu which may be the identity for an ethnic group which has its own distinctive cultural traits including religious system (Pegu, 2012). A great erosion of faith has taken place in the Mising society. It is also found some of the Mising community is being converted to Christianity. The adoption of Christianity, however, has lead to the abolition of traditional faith and practices, festivals and even traditional drinking of rice-beer (Apong). As a result of these changes, the traditional religion of the Misings is losing its original characteristics. The percentage of Mising population practicing Hinduisim ( 98.83 per cent) is witnessed to be highest compared to Christianity ( 0.62 per cent) and others ( 0.56 percent).

Table 2: Changing pattern of Religion and Languages Spokenamong the Misingsin the Sample Survey Villages/Urban Localities of Assam, 2012

\begin{tabular}{|c|c|c|c|c|c|c|c|c|c|c|}
\hline \multirow{3}{*}{$\begin{array}{c}\text { Sample } \\
\text { Survey Area }\end{array}$} & \multirow{3}{*}{$\begin{array}{l}\text { No. of Sample } \\
\text { HHs }\end{array}$} & \multirow{2}{*}{\multicolumn{2}{|c|}{ Religion (\%) }} & \multirow{2}{*}{\multicolumn{2}{|c|}{$\begin{array}{c}\text { Languages Spoken at Home } \\
(\%)\end{array}$}} & \multicolumn{5}{|c|}{ No. of other languages Known (\%) } \\
\hline & & & & & & \multirow{2}{*}{$\begin{array}{c}\text { Past } \\
\text { A }\end{array}$} & \multicolumn{4}{|c|}{ Present } \\
\hline & & Hindu & Chris. & M & $\mathrm{M}+\mathrm{A}$ & & A & $\mathrm{A}, \mathrm{H}$ & $\mathrm{A}, \mathrm{H}, \mathrm{E}$ & A,H,E,B \\
\hline $\begin{array}{l}\text { 1. Somkong } \\
\text { Pagro }\end{array}$ & 30 & 93.3 & 6.7 & 83.3 & 16.7 & 30.0 & 50.0 & 20.0 & 26.6 & 3.4 \\
\hline $\begin{array}{l}\text { 2. No.4 } \\
\text { Ramdhan }\end{array}$ & 30 & 96.6 & 3.4 & 93.3 & 6.7 & 33.3 & 63.3 & 16.7 & 16.7 & 3.3 \\
\hline $\begin{array}{l}\text { 3. Jonai } \\
\text { Bazar }\end{array}$ & 30 & 100.0 & 0.0 & 40.0 & 60.0 & 50.0 & 5.0 & 5.0 & 80.0 & 10.0 \\
\hline $\begin{array}{l}\text { 4. Guwahati } \\
\text { City }\end{array}$ & 60 & 93.3 & 6.7 & 20.0 & 80.0 & 78.3 & 10.1 & 16.6 & 60.0 & 13.3 \\
\hline
\end{tabular}

Source: Primary Survey, 2012.

M-Mising, M+A- Mising \& Assamese, A-Assamese, A,H- Assamese \& Hindi, A,H,E-Assamese, Hindi \& English, A,H, E, B- Assamese, Hindi, Enslish\& Bengali

From the household survey conducted in both rural and urban areas among the Misings, it is found that most of the Misings are influenced by Hinduism. It may be mentioned here that the percentage of Misings practicing Hinduism is higher in JonaiBazar (100 per cent), followed by No.4 Ramdhan (96.6 per cent), SomkongPagro (93.3 per cent) and Guwahati City (93.3 per cent). Although some of the Misings are influenced by Christianity, its proportion is quite low. Among the field study areas, Guwahati city (6.7 per cent) and SomkongPagro (6.7 per cent) have recorded a considerable proportion of Christians in the population (Table 2).

So far as language is concerned, majority of the population in the rural areas are found to speak only Mising language at home. While in the urban areas, although Mising language is spoken at home, the influence of other languages has also been quite significant. Hence, the Misings residing in urban areas practice bilingualism or multilingualism in respect of languages like Assamese, Hindi, Bengali and English.

\subsection{Changing Pattern of Food Habit and Wine Consumption among the Misings}

Food is the symbol of identity of a culture. The framework of food (system) is very complex as the transformation is taking place in food system due to the impact of modernisation. The study of the system of food is very important in shaping a community and its personality. Thus, study of food system fills the gap to understand the tradition, history and changing cultural practices of the community. Though the gradual adaptation is taking place in this respect by the mainstream Mising people to accept the food system of the nontribal communities, it shows the integration of rural Mising culture with urban Mising to construct their identity (Kumari and Dutta, 2012).

Table 3: Changing Pattern of Food Habit and Wine Consumption among the Misings in the Sample Survey Villages/Urban Localities of Assam, 2012

\begin{tabular}{|c|c|c|c|c|c|c|}
\hline \multirow[t]{2}{*}{ Sample Survey Area } & \multirow[t]{2}{*}{ No. of Sample Households } & \multirow{2}{*}{\multicolumn{2}{|c|}{ 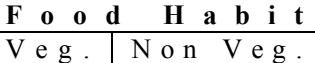 }} & \multicolumn{3}{|c|}{ Win e Cons umption } \\
\hline & & & & L o c a 1 & Foreign & $\mathrm{B}$ ot $\mathrm{h}$ \\
\hline
\end{tabular}


Changing Cultural Practices among the Rural and Urban Mising Tribe of Assam, India

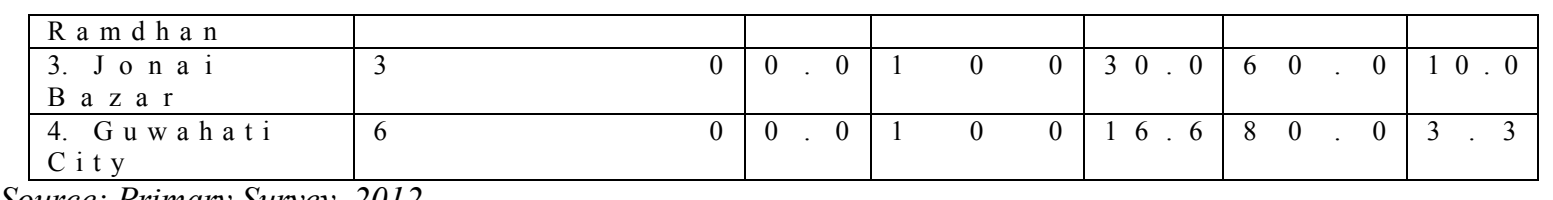

Source: Primary Survey, 2012.

From the household survey conducted in both rural and urban areas among the Misings, it is found that Misings are still maintaining their traditional food habits. It is witnessed that the proportion of Misings consuming non-vegetarian food is almost 100 per cent in all the sample survey areas (Table 3). Although some of the family members in a particular household are found to be vegetarian mainly due to some religious practices or disease, it is not prevalent within the entire household as a whole. The consumption of wine is a common practice among the Misings and they are found to consume basically their traditional rice-beer (Apong). However, in the recent times they are also found to consume the foreign wine. The consumption of traditional rice beer is found to be higher in the rural areas, namely No.4 Ramdhan (53.3 per cent) and 46.7 per cent in SomkongPagro, while the consumption of foreign wine is found to be higher in the urban areas with Guwahati City having 80 per cent and JonaiBazar having 60 per cent (Table 3 ).

\subsection{Inter-community, inter-religion and inter-tribe Marriage among the Misings}

India is still by and large a traditional society with rigid caste system. Caste plays a very important role in the selection of mates in marriages. To most Indians, it is difficult to think of marriage beyond the own caste. To think of marriages between different castes and different religions is a difficult and socially unacceptable proposition. Recently the process of modernization, democratization and development has brought lot of positive changes in Indian society. Similarly, among the Misings of Assam, a marriage within the same community is the norm of the Mising society. But it is being observed that the traditional binding of the community in marriage selection is gradually loosening over time. It is observed that about ten per cent of the marriages among the Misings isinter-community (with non-tribal communities), inter-tribe and inter-religion. This change in the marriage pattern among the community is a very recent phenomenon due to the impact of modernization, socio-cultural interaction, socio-economic development and globalization. Various socioeconomic and demographic factors also affect the pattern of inter-community marriages among them. There is however significant spatial variation in the pattern of inter-community, inter-tribe and inter-religion marriages. There seems to be higher rate of such marriages in socio-economically advanced urban people. It is expected that the incidence of such marriages will increase with the increase in the degree of modernization and socioeconomic development.

Table 4: Inter-Community, Inter-Religion, Inter-Tribe Marriage among theMisings in theSample Survey Villages/Urban Localities of Assam, 2012

\begin{tabular}{|c|c|c|c|c|c|c|c|c|c|c|c|c|}
\hline Sample Survey Area & No. of Sample Households & Inter:Comm & munity llarriage & & gion & & & Tril & Marriage & & ido & \\
\hline 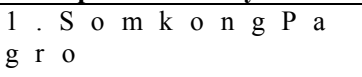 & 0 & $\begin{array}{ll}1 & 0\end{array}$ & 0.0 & 3 & . & 7 & 1 & 3 & . 3 & 0 & . & 0 \\
\hline 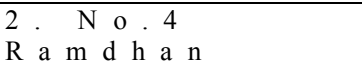 & 3 & 16 & 6.7 & 3 & . & 7 & 6 & & 7 & 3 & . & 7 \\
\hline 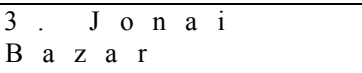 & 3 & 16 & 6.7 & 0 & . & 0 & 6 & & 7 & 0 & . & 0 \\
\hline $\begin{array}{l}4 \text {. } G \text { u w a h a t } \mathrm{i} \text { C } \\
\mathrm{i} \text { t } \mathrm{y}\end{array}$ & 6 & 21 & 1.7 & 3 & . & 3 & 1 & 1 & . 7 & 6 & . & 7 \\
\hline
\end{tabular}

Source: Primary Survey, 2012.

The household survey further reveals that incidence of inter-community, inter-religion, inter-tribe marriage and incidence of widow remarriage is higher in the urban areas compared to the rural ones. The proportion of inter-community (with non-tribal communities) and inter-tribe marriage is found to be as high as 21.7 per cent and 11.7 per cent in Guwahati City, and as low as 10 per cent in SomkongPagro and 6.7 per cent in both JonaiBazar and No.4 Ramdhan (Table 4). It is also witnessed that the proportion of inter-religion marriage is low as compared to the inter-community and inter-tribe marriage with SomkongPagro and No. 4 Ramdhan having 3.7 per cent and Guwahati City having 3.3 per cent of inter-religion marriage. The incidence of widow remarriage is also found to be highest in Guwahati City with 6.7 per cent, followed by No.4 Ramdhan (3.7 per cent), while SomkongPagro and JonaiBazar have no such incidence.

\section{Conclusion}

The major findings and conclusions derived from the study are: 
1. Although the Misings use their mother tongue/dialect among them and most of them know Assamese for conversation with the other communities in the State, some of the urban Misings of younger age group have started forgetting the Mising dialect.

2. The percentage of Mising population practicing Hinduisim (98.83 per cent) is witnessed to be highest compared to Christianity ( 0.62 per cent) and others ( 0.56 percent).

3. The consumption of traditional rice beer is found to be higher in the rural areas, namely No.4 Ramdhan (53.3 per cent) and 46.7 per cent in SomkongPagro, while the consumption of foreign wine is found to be higher in the urban areas with Guwahati City having 80 per cent and Jonai Bazar having 60 per cent.

4. The household survey further reveals that incidence of inter-community, inter-religion, inter-tribe marriage and incidence of widow remarriage is higher in the urban areas compared to the rural ones. The proportion of inter-community (with non-tribal communities) and inter-tribe marriage is found to be as high as 21.7 per cent and 11.7 per cent in Guwahati City, and as low as 10 per cent in SomkongPagro and 6.7 per cent in both JonaiBazar and No.4 Ramdhan.

\section{References.}

[1] Barman, S (2004): "Pattern of Socio-Economic Change Among Different Communities inChakchaka Development Block of Barpeta District, Assam, an unpublished M.Phil dissertation, Gauhati University.

[2] Bhagat, R.B. (1990): "Status of women and Age at Marriage in India", Social Change, Vol.20 (2), pp.20-25.

[3] Bordoloi, B.N., Sharma Thakur, G.C. and Saikia, M.C. (1987): Tribes of Assam, Part-1, Tribal Research Institute, Guwahati

[4] Chauhan, A. (1990): Tribal Women and Social Change in India,Vikas Publishing House, New Delhi.

[5] Chungkurang, M. (2006): “The Ke'bang System of Local Self-Administration of Misings", Promising Action, Sept-Oct, pp 4-5.

[6] Das,K., Das, K.C., Roy, T.K. and Tripathy, P.K. (2011): "Dynamics of inter-religious andinter-caste marriages in India" presented in Population Association of 2011 Annual Meeting Program, Washington, D.C.

[7] Das, M. (2008): "Education, Occupation and Social Change: Towards a Social Geography ofTribal Women in Assam", An unpublished Ph.D. Thesis, Gauhati University.

[8] Doley, D. (2012): "Mising People and Language" in MuktinathPegu(ed.) BayugnamGomsar, Mising AgomKebang, Jorhat, pp. 7 16.

[9] Doley, M. (1987): "The Role of Mishing Women in their Economy", Bulletin of the Research Tribal Institute, Assam, Vol.1 No. V, pp. 53-55.

[10] Doley, P. (2013): "The Misings in the Rural and Urban Context of Assam: The Case of Jonai Revenue Circle of Dhemaji District and Guahati City", An unpublished Ph.D. Thesis, Gauhati University.

[11] Kaman, R. (2012): “Changing Mising Religion” in Royal Pegu (ed.) SiyangBoggo, A Souvenir of Mising AgomKebang $20^{\text {th }}$ Biennal Conference at Jonai, pp. 178-182.

[12] Kar, B.K. (2007): "Population" in A.K. Bhagabati et al (eds) Geography ofAssam, Rajesh Publications, New Delhi, pp.115-155.

[13] Kumari, P and Dutta, S.K. (2012): "Changing Eating Pattern of Mising Food Culture", International Journal of Humanities and Social Sciences, Vol.2, No.2, pp. 211-219.

[14] Pegu, L.N. (2006): "Impact of Hinduism and Other Religions on Mising Religious Beliefs", Promising Action, Jan-Feb, pp. 7-9.

[15] Pegu, I. (2012): "Educational Problems of Mising Tribe" in Royal Pegu (ed.) SiyangBoggo, A Sovenir of Mising AgomKebang $20^{\text {th }}$ Biennal Conference at Jonai, pp. 183-184.

[16] Pegu, R. (2012): "The Socio-Economic Changes of Mising People of Assam in Late Twentieth Century" in Royal Pegu (ed.) SiyangBoggo, A Souvenir of Mising AgomKebang, 20 $0^{\text {th }}$ Biennal Conference at Jonai, pp. 191-194.

[17] Pegu, R.K. (2012): "Hinduisation and Identity Conflict: The Mising Case" IJCAES Special Issue on Basic, Applied \& Social Sciences, Volume II, pp. 390-391.

[18] Perme, R. (2005) Strengths of Mising Community, Promising Action, July-Aug, pp.6-8

[19] Singh, R.P.B. \& Singh, R.S. (2004): "Cultural Geography" in H.N. Sharma (ed.) Progress in Indian Geography, 2000-2004, $30^{\text {th }}$ IGC, Glasgow, pp. 133-139.

[20] Taher, M. and Ahmed, P. (2007): Geography of North-east India, Mani ManikPrakash, Guwahati,

[21] Taye, N.C. and Saikia, A. (2005): "Mising Woman in the Conduit of Culture", Promising Action, March-April, pp. 9-13.

[22] Tukbo, T. (2005): “Cultural Affinity of the Tani: Group", Promising Action, July-August, pp.12-13.

[23] Yein, B. (2005): “Ali: A:yeLigang”, Promising Action, Jan-Feb, pp.6-7.

[24] Census of India , 2001: Primary Census Abstract, Assam.

Websites:

http://pib.nic.in/feature/feyr2001/fmay2001/f030520011.htmlaccessed on 10/10/2012. 